\title{
Yield Performance of the Promising Cocoa Hybrids (Theobroma cacao L.) at Dry Climate Condition
}

\author{
Agung Wahyu Susilo ${ }^{1^{*}}$ \\ 1)Pusat Penelitian Kopi dan Kakao Indonesia, Jalan PB Sudirman No 90, Jember, Indonesia \\ ${ }^{*}$ Corresponding author: soesiloiccri@yahoo.com \\ Received: 1 January 2018 / Accepted: 12 February 2018
}

\begin{abstract}
Global climate change is impacting cocoa cultivation that cocoa trees must be adaptive in dry climate and higher temperature of environmental condition. This research had objective to observe adaptability performance of the promising hybrids of cocoa of the selecting high yielding hybrids which are tolerant to dry condition. Treatments were 14 hybrids of bi-clonal crosses between selected clones in factorial design in which KEE 2 was selected based on its resistance to vascular-streak dieback (VSD) and drought condition. Multilocation trials were established in Kaliwining Experimental Station in Jember (low land) and Sumber Asin Experimental Station in Malang (medium land) both of which were classified to dry land area. Yield per tree were assessed in monthly basis during 9 consecutive years of yield period. Data were performed to the combined analysis of variance followed by AMMI (additive main effect and multiplicative interaction). The results showed that the factor of hybrid, location, and interaction of hybrid and location to year contributed higher value of variance for the yield. Analysis of AMMI indicated that the hybrids of KEE 2 x Sulawesi 1 ( $\mathrm{F}_{1}$ and reciprocal) had highest yield potency and adaptive to low land (Kaliwining) on the other hand the hybrids of TSH 858 x KEE 2 ( $F_{1}$ and reciprocal) were adaptive to medium land (Sumber Asin). Refer to yield adaptability to dry condition and other potential traits reported thus the hybrid of KEE 2 x Sulawesi 1 ( $F_{1}$ and reciprocal) was released as cocoa planting material for addressing dry condition. The result also identified those hybrids inherited using KEE 2 performed more adaptive to dry condition. Furthermore, the clone was suggested to be used as parental clone on breeding for drought tolerance.
\end{abstract}

Key words: hybrid, Theobroma cacao L., dry climate, yield perfomance

\section{INTRODUCTION}

Planting material is a key factor on sustainable cocoa cultivation but there was just a few farmers adopting high quality planting materials which account for $25 \%$ of cocoa farm developed using the recommended planting materials (Laliberté \& End, 2015). Planting materials consist of genetic messenger for the economical traits such as yield, bean quality, resistance to pests and diseases, in which the expressions are affected by geneticenvironmental interaction. Cocoa planting materials were developed using two propagation methods; vegetative (clonal) and generative (hybrids) each of which were specified according to the genetic homogeneity, technical method on propagation and difficulty in distributing the seedlings. Adoption of the technology by farmers varies depending on their technical skill and knowledge refer to the specification. Hybrid materials are widely 
adopted by farmers due to easier in distribution and propagation even the cocoa trees derived from hybrids are heterogeneous as the impact of intercrossing between non-inbred lines of parental clones. Wibaux et al. (2017) reported the yield of cocoa farm derived from hybrid in which were accounted for $46 \%$ of total yield produced by $20 \%$ of trees then others trees contributed the rest amount of the yield. Furthermore strategy to optimize production of cocoa plantation using hybrids is by rehabilitating the unproductive trees using side grafting technique with high yielding clones. Clonal material is more homogenous variety that would be more productive than hybrid. However farmers have less skill in adopting the clonal materials, therefore only a few farmers are able to develop clonal planting materials. Furthermore development of cocoa planting materials should refer to farmer skill in adopting the propagation technique.

Nowadays clonal materials of cocoa are more popular adopted by farmer in the cocoa growing area as the improvement of farmer skill on propagation technique that increase production significantly. Hybrid seedlings are still preferred and easier adopted by less experienced farmers and used as rootstock seedlings for clonal grafting. During the last 12 years demand for hybrid cocoa seeds reach up to 12 million per year (Anita-Sari \& Susilo, 2015) which are much higher than the demand for clonal seedlings due to the limitation on mass scale clonal propagation using conventional method. Refer to the success story on Indonesia cocoa development in 1980's wherein cocoa area, prodution increased rapidly due to the supporting of hybrid seeds. Since that time, in contrary cocoa breeding program focused on selecting clonal materials not to improve genetic potency of hybrid varieties due to clonal materials was assummed going to be more productive than hybrids in improving cocoa productivity (Susilo et al., 2013). Since early 2000's breeding program focused on selecting high yielding clones which resistant to main pests and diseases, eventually some cocoa clones with specification of the resistance to pod rot diseases (Phytophthora palmivora), cocoa pod borer (Conopomorpha cramerella Snell.), and vascular-streak dieback (VSD, Ceratobasidium theobromae) were released. Development of the cocoa clones was limited with the availability of budwood so that the mass production was supported by in vitro culture using somatic embryogenesis technique (SE). This process was able to support government program on fulfilling the requirement of clonal seedlings for rejuvenation in the acreage of 70,000 ha during the year of 20092011 (Puslitkoka, 2012). In parallel with the clonal seedlings development thus cocoa breeding was re-focused to select hybrids which had resistance to VSD as the main issue urgently to be addressed that in 2010 the hybrid of ICCRI $06 \mathrm{H}$ for controlling VSD in Indonesia was released (Susilo, 2011).

Breeding for cocoa hybrid has being continued with more focus to select tolerant hybrids in drought condition rather than resistance to VSD. Climate change has negative impact in cocoa production as the existing cocoa farm production was hampered by longer dry season (de Rozari et al., 1992) and the utilization of huge potency area of dry area in acreage of 13.3 ha in the eastern part of Indonesia for expanding cocoa development (Mulyani \& Sarwani, 2013). Climate change has high potency to increase air temperature $\left(0.5-1^{\circ} \mathrm{C}\right)$, the outbreaks of pests and diseases and decreasing soil fertility due to soil erosion at the impact of abnormal rainfall (Ramirez-Villegas et al., 2012). The increasing air temperature will trigger plant trees in longer dry season that may decrease plant resistance to VSD. Therefore cocoa breeding for drought tolerance has to be an object in parallel with breeding for VSD resistance in supporting integrated 
technology for mitigating climate change on cocoa.

Breeding on cocoa hybrid tolerant to drought condition was carried out by intercrossing among selected clones which were specified in yield potency, bean quality, cross compatibility and resistance to VSD. Of the parental clones, there was KEE 2 which was selected based on its resistance to VSD, and general cross compatibility (Suhendi et al., 2000) and further evaluation performing field-tolerance to drought condition (Susilo, 2015). Therefore the progeny of KEE 2 would be more resistant to VSD and more tolerant to drought condition. Multilocation trials of the promising hybrids were established in dry locations which be specified with the differences on altititude for 9 years of yield period (2006-2015) to observe the stability performance of the yield. Previously the stability analysis of tested hybrids in different agro-climatic condition covered wet climate area has been reported (Susilo, 2011). Objective of this research was to support the previous report with longer time of yield evaluation and more focused at dry location that could select adaptive hybrids at dry condition for eventually releasing the drought tolerant cocoa planting materials. This result will be discussed through the recommendation of selected hybrids as part of technology for mitigating climate change in Indonesia.

\section{MATERIALS AND METHODS}

Treatments for multilocation trial consisted of 15 hybrids generated by intercrossing between selected parental clones of Sulawesi 1 , Sulawesi 2, TSH 858, KEE 2, NIC 7, ICS 13 and KW 165 in factorial design of which two hybrids as control, namely ICS $60 \mathrm{x}$ Sca 12 and the new released hybrid of ICCRI $06 \mathrm{H}$ (TSH $858 \times$ Sulwesi $1, \mathrm{~F}_{1}$ and reciprocal). The hybrid of ICCRI $06 \mathrm{H}$ was released as cocoa planting material for controlling VSD based on the Decree of Ministry of Agriculture No. 3682/Kpts/ SR.120/11/2010.

Multilocation test was carried out in two locations which representing the dry climate area, namely Kaliwining Experimental Station in Jember District (low land) and Sumber Asin Experimental Station in Malang District (medium land) both of which were managed by Indonesian Coffee and Cocoa Research Institute (ICCRI). Of the locations, Kaliwining represented VSD endemic area that the hybrids would be also tested for their resistance to VSD. Trials were established in the randomized block design with 4 blocks as replications in each plot consisted of 1628 trees (Table 1). Trees were planted in $3 \mathrm{~m} \times 3 \mathrm{~m}$ of spacing distance under shade trees of Leucaena glauca and Glyricideae. Assessment of yield by recording pod number per tree in the interval of one month during 9 consecutive years of 2006-2015 then the number of pods per tree was converted to yield using pod index.

Location for multilocation trials were specified with dry condition in which the recorded data of precipitation during the yield assessment were for 2006-2016. Average of rainfall per year in Kaliwining Expt. Station was $2,091 \mathrm{~mm} /$ year and in Sumber Asin Expt. Station was 2,247 mm/year. Q-value was calculated to identify the climatic condition year by year during yield assessment. Q-value is the number of dry month divided by the number of wet month refers to Schmidt \& Ferguson (1959) then the climate condition were classified as A (0.00$0.43)$ very wet; $B(0.143-0.333)$ wet; C (0.333-0.600) moderately wet; D (0.6001.00) moderate; E (1.00-1.67) moderate dry; F (1.67-3.00) dry; G (3.00-7.00) very dry; and $\mathrm{H}(>7.00)$ extra dry.

The recorded data were performed the combined-analysis of variance to observe the factors affecting yield. Further analysis 
Table 1. The situation of selected locations for testing the promising hybrids at multilocation trial

\begin{tabular}{|c|c|c|c|c|c|}
\hline Location & $\begin{array}{l}\text { Altitude } \\
\text { (m asl.) }\end{array}$ & Latitude & Longitude & $\begin{array}{c}\text { Climate } \\
\text { classification }^{1)}\end{array}$ & $\begin{array}{l}\text { Number of } \\
\text { trees per plot }\end{array}$ \\
\hline $\begin{array}{l}\text { Kaliwining Experimental } \\
\text { Station, Jember (low land) }\end{array}$ & 45 & $8^{\circ} 15^{\prime} 43.74^{\prime \prime} \mathrm{S}$ & $113^{\circ} 36^{\prime} 19.08^{\prime \prime} \mathrm{E}$ & $\mathrm{D}$ & 16 \\
\hline $\begin{array}{l}\text { Sumber Asin Experimen- } \\
\text { tal Station, Malang } \\
\text { (medium land) }\end{array}$ & 600 & $8^{\circ} 16^{\prime} 50.29^{\prime \prime} \mathrm{S}$ & $112^{\circ} 42^{\prime} 44.81^{\prime \prime} \mathrm{E}$ & $\mathrm{C}$ & 28 \\
\hline
\end{tabular}

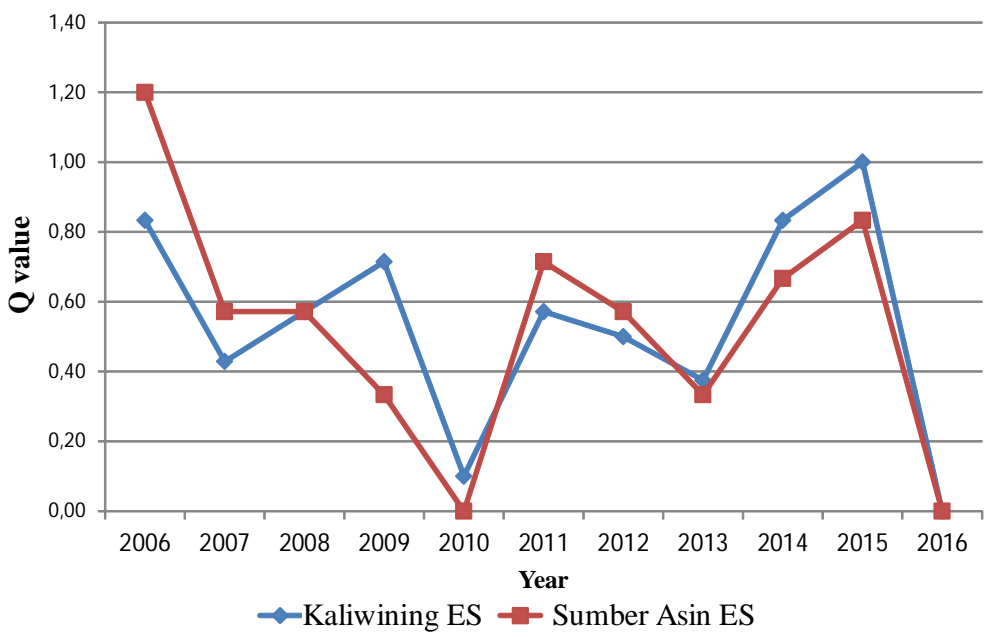

Figure 1. Dynamic of Q-value for 2006-2016 representing the climate condition at locations of Kaliwining and Sumber Asin Experimental Stations

used AMMI (Additive Main Effect and Multiplicative Interaction) biplot graph (Yan \& Kang, 2003) to overview the adaptability performance of the tested hybrids.

\section{RESULTS AND DISCUSSION}

The combined analysis of variance for yield of the recorded data indicated the significant effects of hybrid, year, location and their interaction (Table 2). Result of the analysis showed the factor of year gave higher contribution to the variance as yearly differences were so high due to the impact of seasonal fluctuation and plant growth. The effect of interaction between hybrid and location possibly indicated any specific hybrid which adapted to the specific location wherein classified by altitude differences. Yang et al. (2010) reported there were any differences of the adaptation response among poplar species (Populus sp.) to different altitude of dry climate area in which the response differences influenced by physio-logical and proteomic mechanism. This research was aimed to explore the promising hybrids having tolerance to drought condition but would be widely adapted to various altitudes level.

The graph of AMMI biplot (Figure 2) figure out the ordinate position of location and hybrid refer to the time (year) of production. The location of Kaliwining (low land) performed better supporting the yield rather than Sumber Asin (medium land) and there was also the difference of hybrid adaptation at the locations as classified according to their altitude level. The climate condition at lower altitude would get higher intensity of sunshine 
than higher altitude where more sunshine would better supporting the physiological process on cocoa flowering (de Almeida \& Valle, 2008). Altitude mostly impact temperature level where in higher altitude tend to have lower temperature that cocoa may not well adapted up to the altitude level situated with temperature below $18-21^{\circ} \mathrm{C}$ (Wibawa \& Baon 2008). Therefore the higher land would be less favorable to cocoa growing but higher land would less disease incidence, especially VSD (Anita-Sari et al., 2017). Cocoa is tree which well adapted in the altitude between 0-600 meters above sea level ( $\mathrm{m}$ asl.) (Baon et al., 2015).

HKW 6 and HKW 9 belong to the crosses of Sulawesi 1 x KEE $2\left(\mathrm{~F}_{1}\right.$ and reciprocal) performing highest yield potency and adaptive in Kaliwining. The parental clones were selected for its resistance to VSD, however KEE 2 also had tolerance to drought condition in which of the selected progeny using KEE 2 as male parent, namely KW 411 performed tolerant to drought condition (Susilo, 2015). Both hybrids of HKW 6 and HKW 9 were also reported performing field resistance to VSD in Kaliwining as the VSD-endemic area (Susilo \& Anita-Sari, 2011). Other than those potencies, HKW 6 and HKW 9 performed higher yield potency than ICCRI $06 \mathrm{H}$ (HKW 2 and HKW 10) and the open-pollinated hybrid of ICS 60 x Sca 12 as control that both of the promising hybrids could be recommended as planting materials for addressing VSD and dry condition. Otherwise to select stable hybrid, HKW 2 and hybrid of ICS 60 $\mathrm{x}$ Sca 12 performed more stable hybrids in both locations as their ordinate points placed down close to point axis line. Other hybrids which performed more adaptive in Sumber Asin (medium land) namely HKW 1, HKW 3, HKW 5 and HKW 7 that would be adaptive hybrid in other medium land situated with dry condition. Those hybrids were also generated by KEE as of the parent that could be concluded KEE 2 is effective clone to inherit hybrids which tolerant to drought condition.

Figure 3 and 4 showed differences on yield potency among tested hybrids in each location that may be interpreted the effect of genotype by environment interaction. Based on the results, it was known that HKW 6 (KEE 2 x Sulawesi 1) performed highest production in Kaliwining (Figure 3) and HKW 1 (TSH 858 x KEE 2) performed highest production in Sumber Asin (Figure 4). It was also reported that the resistance of TSH 858 $\mathrm{x}$ KEE 2 to VSD was moderate susceptible (Susilo \& Anita-Sari, 2011) that would be less productive in Kaliwining as an VSDendemic area than in Sumber Asin. The mean of parental clones indicated that Sulawesi 1 performed higher yield potency than TSH 858 and KEE 2, both of which were used as male

Table 2. The combined analysis of variance for yield performance $(\mathrm{kg} / \mathrm{tree})$ at the multilocation trial of promising cocoa hybrids during the year of 2006-2015

\begin{tabular}{lcrrr}
\hline Source of variation & Degree of freedom & Sum square & Mean of sum square & $\mathrm{F}_{\text {calculated }}$ \\
\hline Hybrid (H) & 14 & 77.63 & 5.54 & $8.8^{*}$ \\
Block (B) & 2 & 6.55 & 2.18 & $3.46^{\text {ns }}$ \\
Year(Y) & 9 & 828.14 & 92.01 & $145.95^{*}$ \\
Location (L) & 1 & 186.38 & 186.38 & $295.64^{*}$ \\
H x Y & 126 & 128.55 & 1.02 & $1.62^{*}$ \\
H x L & 14 & 102.96 & 7.35 & $11.67^{*}$ \\
Y x L & 9 & 177.58 & 19.73 & $31.30^{*}$ \\
H x Y x L & 126 & 89.67 & 0.71 & $1.13^{*}$ \\
Error & 897 & 565.51 & 0.63 & - \\
Total & 1,199 & $2,162.99$ & - & - \\
\hline Note: Fisher test indicate significant differen & $*$ & &
\end{tabular}

Note: Fisher test indicate significant different $\left({ }^{*}\right)$ and not significant different (ns) at $\alpha=1 \%$. 


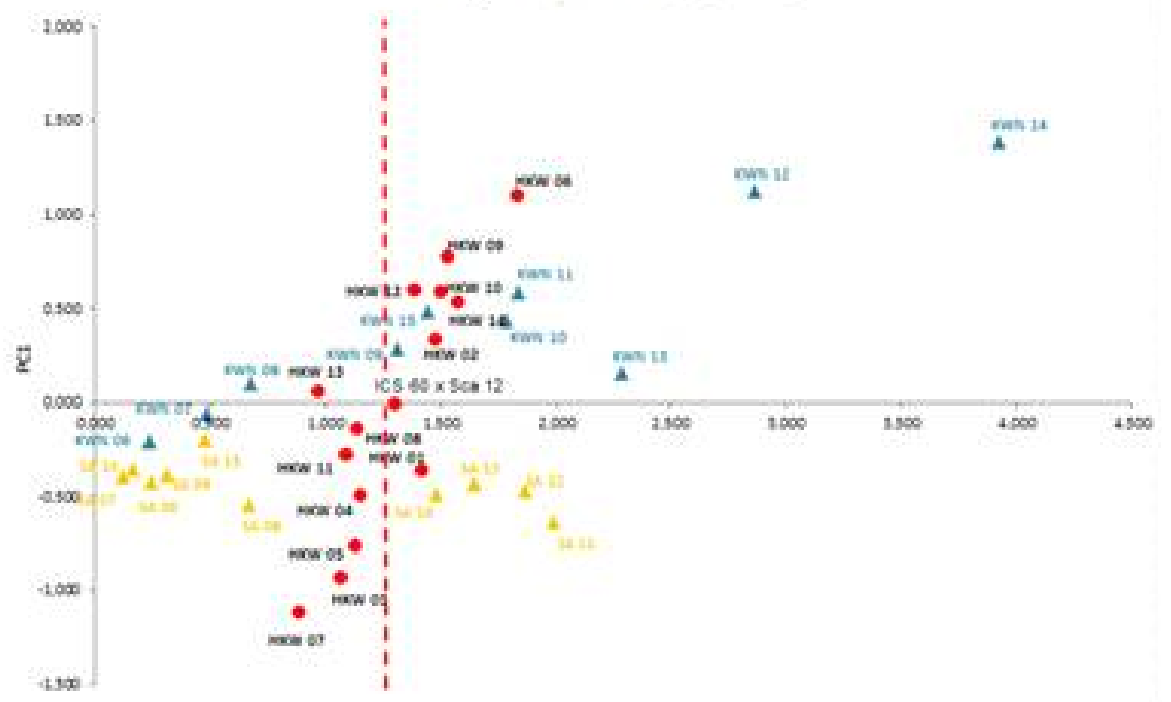

Figure 2. The graph of AMMI biplot for yield ( $\mathrm{kg} / \mathrm{tree})$ of the promising cocoa hyhrids which were tested in multilocation trial in Kaliwining (low land) and Sumber Asin (medium land) during the year of 2006-2015: HKW 1 = TSH 858 x KEE 2; HKW 9 = Sulawesi 1 x KEE 2; HKW 2 $=$ TSH 858 x Sulawesi 1 (ICCRI 06H, F $)$; HKW 10 = Sulawesi 1 x TSH 858 (ICCRI 06H, reciprocal); HKW 3 = TSH 858 x NIC 7; HKW 11 = Sulawesi 1 x NIC 7; HKW 4 = TSH 858 x ICS 13; HKW 12 = Sulawesi 1 x ICS 13; HKW 5 = KEE 2 x TSH 858; HKW 13 = Sulawesi $2 \times$ KEE 2; HKW $6=$ KEE $2 \times$ Sulawesi 1 ; HKW $14=$ KW $165 \times$ KEE 2; HKW $7=$ KEE $2 \times$ NIC 7; KWN = Kaliwining Experimental Station; HKW $8=$ KEE $2 \times$ ICS 13; and SA = Sumber Asin Experimental Station

or female (Table 3). This result could be suspected that Sulawesi 1 had better combining ability for yield in which it may be better crossed with KEE 2 as the best combination to generate high yielding hybrid resistance to VSD and tolerance to drought condition. Analysis of combining ability on cocoa was reported there were any differences of general and specific combining ability among tested clones. Suhendi et al. (2004) reported that KEE which of the clone having general combining ability but the best crosses was reported with TSH 858 for percentage of flowering. It was also previously reported that KEE 2 be classified as clone which having general combining ability for cross compatibility (Suhendi et al., 2000).
The results significantly informed the high contribution of year factor to total variance that mean year was the main environmental factor influenced the yield. The climatic conditions changed yearly in similar pattern at both locations varied between moderate dry to wet (Figure 1). The climate condition at the location for 2006-2015 could be classified in three major conditions, namely wet, moderate and moderate dry. In average the climate were in moderate condition but two extremely sistuation happened in which climate condition was moderate dry in 2006 and 2015 and wet in 2010. The condition influenced significantly to the yield performance wherein average yield in 2015 were less than yield in 2010 . It could be under- 


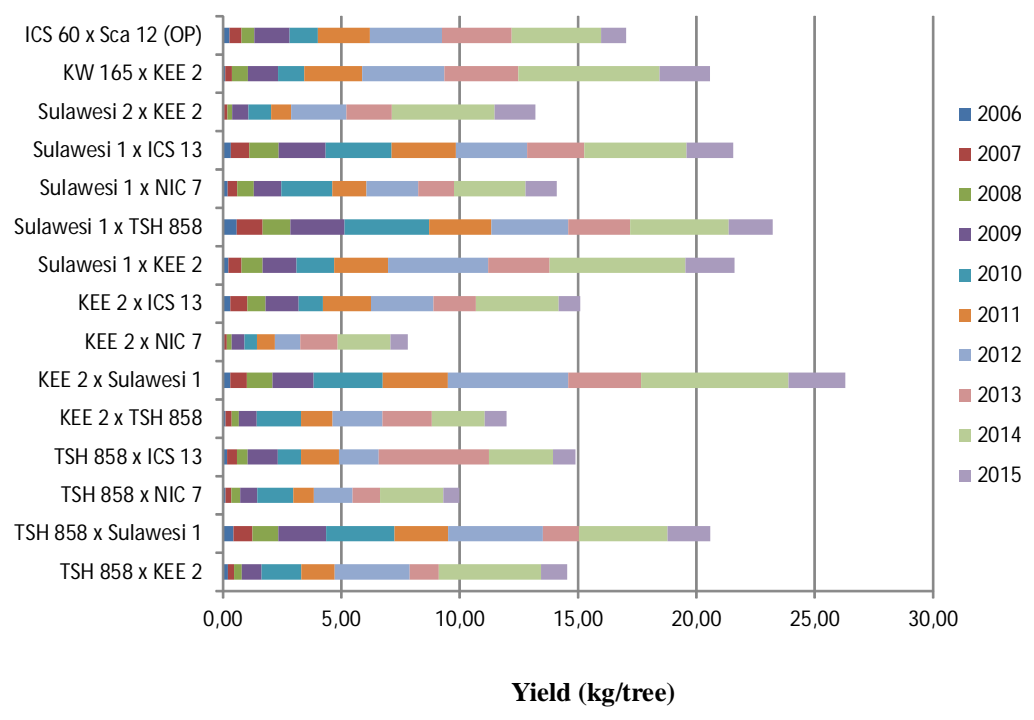

Figure 3. Yield performance of the promising cocoa hybrids which were tested at Kaliwining Experimental Station during the year of 2006-2015

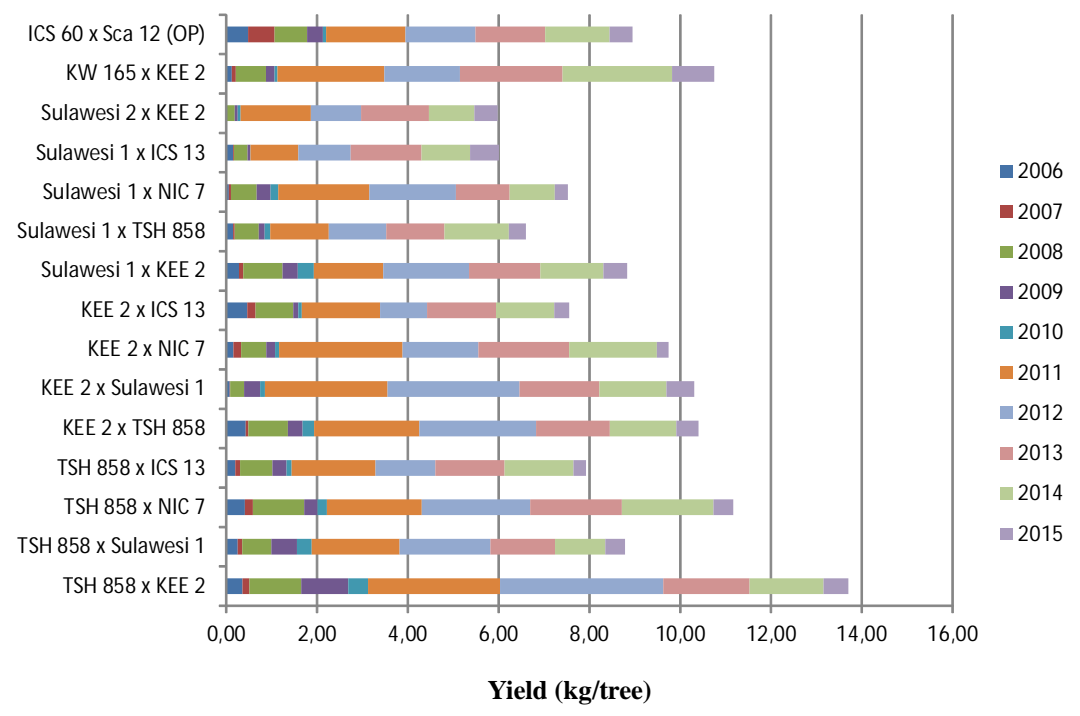

Figure 4. Yield performance of the promising cocoa hybrids which were tested at Sumber Asin Experimental Station during the year of 2006-2015

Table 3. Productivity of parental clones when used as female or male

\begin{tabular}{lcc}
\hline Clones & Mean as female parent & Mean as male parent \\
\hline TSH 858 & 1.44 & 1.31 \\
Sulawesi 1 & 1.51 & 1.65 \\
KEE 2 & 1.47 & 1.47 \\
\hline
\end{tabular}


stood as cacao yield is strongly related to rainfall in the dry season. Leite \& Valle cit. de A lmeida \& Valle (2008) reported the study in Bahia that high capacity of cocoa yield could be reach when the monthly total rainfall more than $200 \mathrm{~mm}$ while the permanence of water table should more than 30 days. In other study Zuidema et al. (2005) reported that over $70 \%$ of yield variation could be explained by a combination of annual radiation and rainfall during the two driest months. In regard to the climate condition at the trial location, dry month normally started in June then prolonged up to 3.6 months in average in Kaliwining and 3.4 months in average in Sumber Asin. The higher yield performance was observed in 2012 and 2014, in the similar pattern at both locations but relatively different of the values between location and hybrids.

\section{Yearly Production Distribution}

Dynamic of yield through the year is an important information that breeders are able to classify which of the hybrids perform continuous or discontinuous pod bearing as the basic recommendation for farmers. The results showed that hybrid of HKW 6 (Sulawesi $1 \times$ KEE 2) and HKW 9 (KEE 2 $x$ Sulawesi 1) and also the control of ICCRI $06 \mathrm{H}$ and ICS $60 \times$ Sca 12 performed continuously bearing pod through month of the year. However, there were any differences on peak season of cocoa production both in Sumber Asin and Kaliwining (Figure 5). Peak season of cocoa production in Kaliwining (low land) occured in two main crop seasons, namely August and December but in Sumber Asin (medium land) occured mainly only in September. Cocoa has cauliflowers and the flowering were influenced by environmental condition, such as temperature and rain fall distribution all the year (de Almeida \& Valle, 2008). Furthermore, climate type and altitude would so important influencing the pattern of harvest time. Prawoto (2014) reported the peak season of harvest time on cocoa in Kaliwining occured in the period of May to November but low season of harvest time was observed in December up to April in the following year. In term of economic perspective, planters prefer cocoa trees which discontinuously bearing pod to reduce labor cost for harvest but smallholder farmers prefer trees which continuously bearing pod to assure the sustainability of household income through the year.

\section{Yield Performance Variability}

Cocoa hybrids genetically perform variation due to segregation process when crosses between heterozygous clones. The heterozygosity level of cocoa germplasm in Indonesia was reported in variation between 20.0-86.7\% (Susilo et al., 2013) that crosses between parental clones will impact to genetic segregation through $\mathrm{F}_{1}$ population. The result showed variation of individual yield potency through hybrid of Sulawesi 1 x KEE $2\left(\mathrm{~F}_{1}\right.$ and reciprocal) (Figure 6) in which could be confirmed the segregating population of genotypes belong to the hybrids. It showed that the population hybrid of Sulawesi 1 x KEE 2 and KEE $2 \times$ Sulawesi 1 consisted of individual genotypes which varied in their yield potency compared with control. Considering the distribution of individual genotype it could be observed that number of genotypes having yield potency higher than control was equal to number of genotypes having yield potency less than control meaning that half number of genotypes belong to Sulawesi 1 $\mathrm{x} \operatorname{KEE} 2\left(\mathrm{~F}_{1}\right.$ and reciprocal $)$ performing high yielding potency or higher than control. Susilo (2011) previously reported similar pattern of distribution belong to the hybrid of TSH 858 $x$ Sulawesi $1\left(F_{1}\right.$ and the reciprocal $)$ which was released as ICCRI $06 \mathrm{H}$. 

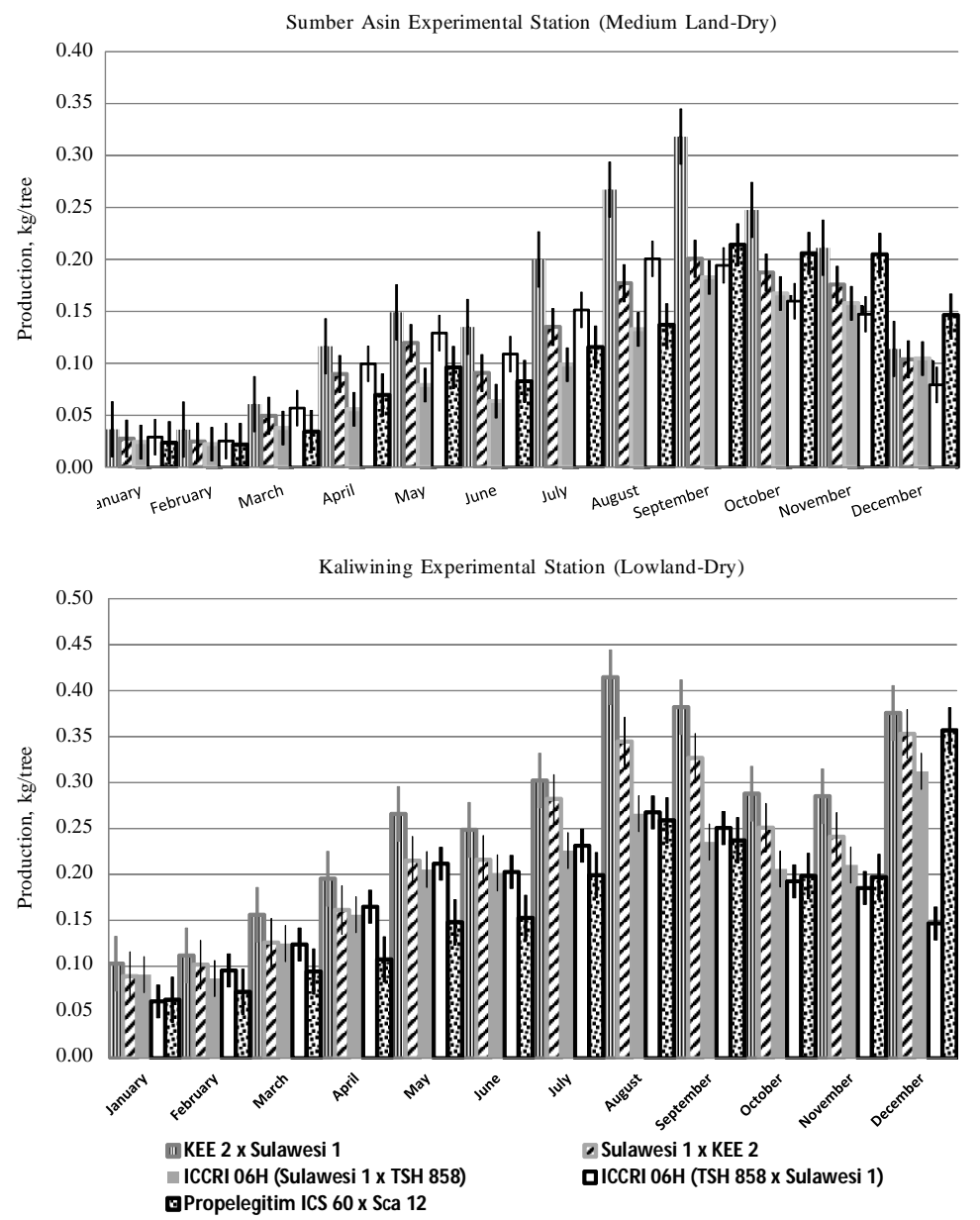

Figure 5. Distribution of monthly yield ( $\mathrm{kg} /$ tree) through the years of the most promising hybrids in KP Kaliwining and KP Sumber Asin (bars indicate standard deviation of means)

From the previous discussion of the result it could be concluded that the promising hybrid of Sulawesi $1 \times$ KEE $2\left(\mathrm{~F}_{1}\right.$ and reciprocal) may be recommended as cocoa planting materials in respect to high yield potency and resistant to VSD and tolerant to drought condition. The hybrids was also reported to have moderate tolerant to Phytopthora pod rot (PPR) and bean quality fulfilled A category (>1 g/dry bean) refer to SNI (Indonesian National Standard) and fat content of nib reach up to $>50 \%$ therefore the hybrid was qualified as cocoa planting material (Susilo et al., 2016). Refer to the potency the hybrid of Sulawesi 1 x KEE 2 $\left(F_{1}\right.$ and reciprocal) was released as high quality of cocoa planting material according to the decree of the Ministry of Agriculture No.108/Kpts/KB.021/2/2017 then renamed with ICCRI $08 \mathrm{H}$ following numbering system of the previous hybrid of ICCRI $06 \mathrm{H}$. Seed production of ICCRI $08 \mathrm{H}$ was established using seed garden with parental clones of Sulawesi 1 and KEE 2 in the proportion of 2:1 refer to yield inheritance of Sulawesi 1 which was higher than KEE 2. Hybrid seeds can be harvested from pods of both the parental clones, Sulawesi 1 or KEE 2, as reported that there was no significant difference of the yield performance between $\mathrm{F}_{1}$ and the reciprocal that indicate no maternal effect on the yield inheritance. 

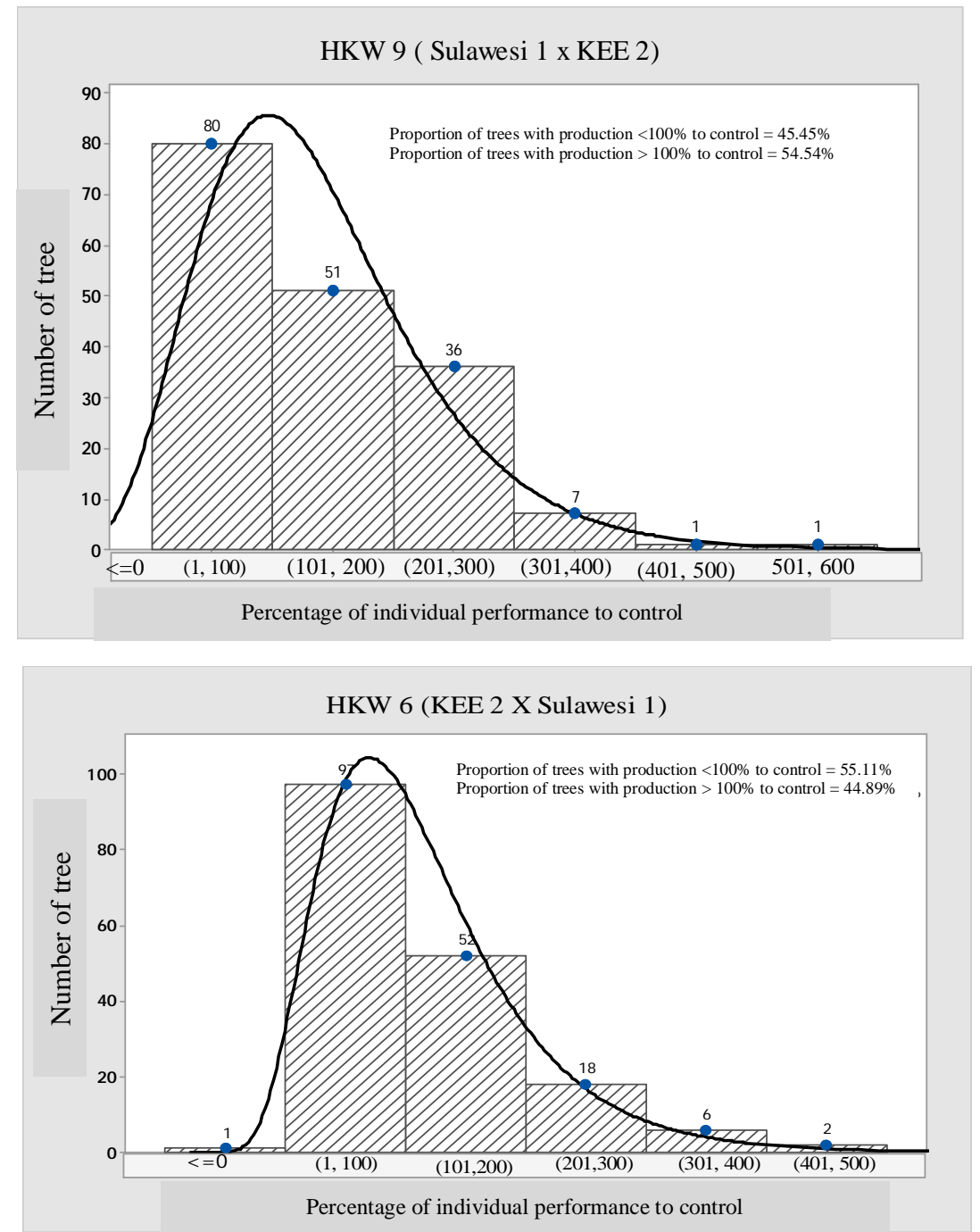

Figure 6. Relative of performance of individual tree on yield compared to control through the hybrids of Sulawesi 1 x KEE 2 and KEE 2 x Sulawesi 1

\section{CONCLUSIONS}

Evaluation of the yield performance of tested hybrids at dry climate area selected the most adaptive hybrid to dry area, namely Sulawesi 1 x KEE $2\left(\mathrm{~F}_{1}\right.$ and the reciprocal) which had higher value of the yield compared to ICCRI $06 \mathrm{H}$ and the open pollinated hybrid of ICS $60 \mathrm{x}$ Sca 12. Hybrid of Sulawesi $1 \mathrm{x}$ KEE $2\left(\mathrm{~F}_{1}\right.$ and the reciprocal $)$ performed yield potency in amount of 2.24 and $2.47 \mathrm{~kg} /$ tree/ year, respectively, higher than ICCRI $06 \mathrm{H}$ and the open pollinated hybrid of ICS $60 \mathrm{x}$
Sca 12 in amount of $2.31 \mathrm{~kg} /$ tree/year and $1.79 \mathrm{~kg} /$ tree/year respectively. Therefore, the crosses combination of Sulawesi 1 and KEE 2 ( $F_{1}$ and the reciprocal) is the best crosses to generate progenies which are more resistant to VSD and tolerance to dry condition.

\section{AKNOWLEDGMENT}

The authors wish to thanks the Director of ICCRI for his permission publishing this paper. Thanks also dedicated to persons 
who significantly contributed in the technical aspect in field and laboratory work; breeding team works such as Indah AnitaSari, Bayu Setyawan, Sukarmin and Rudi Hartoyo; field team works such as the head of Experimental Stations of Sumber Asin and Kaliwining for their support maintaining experimental trial.

\section{REFFERENCES}

Anita-Sari, I. \& A.W. Susilo (2015). Peluang dan tantangan perbenihan kakao di Indonesia. Warta Pusat Penelitian Kopi dan Kakao Indonesia, 27, 6-13.

Anita-Sari, I; A.W. Susilo; N. Puspitasari, F. Nuraini, B. Setyawan, P. McMahon \& P. Keane (2017). Intensity of vascular streak dieback in different cocoa clones and various agro-climatic conditions. Pelita Perkebunan, 33, 1-9.

Baon, J.B.; S. Abdoellah \& Pujiyanto (2015). Persyaratan tumbuh. p. 1-3. In: Misnawi; A.W. Susilo; J.B. Baon; A.A. Prawoto \& E. Sulistyowati (Eds.). Pedoman Teknis Budidaya Kakao (Theobroma cacao L.). Pusat Penelitian Kopi dan Kakao Indonesia, Jember.

de Almeida, A-A.F. \& R.R. Valle (2008). Review: Ecophysiology of the cacao tree. Brazilian Journal of Plant Physiology, 19, 425-448.

de Rozari, M.B.; R. Hidayati \& M.E. Manan (1992). Perubahan iklim di Indonesia. Jurnal Agromet, 8, 1-8.

Laliberté, B. \& M. End (2015). Supplying New Cocoa Planting Materials to Farmers: A Review of Propagation Methodologies. Bioversity International, Rome, Italy.

Mulyani, A. \& M. Sarwani (2013). Karakteristik dan potensi lahan sub optimal untuk pengembangan pertanian di Indonesia. Jurnal Sumberdaya Lahan, 7, 47-55.

Prawoto, A. (2014). Pattern of flushing, cherelle wilt, and accuracy of yield forecasting of some cocoa clones. Pelita Perkebunan, 30, 100-114.
Puslitkoka (2012). Keragaan Kakao Somatic Embryogeneis (SE) pada Peremajaan GERNAS kakao 2009-2011. Pusat Penelitian Kopi dan Kakao Indonesia, $41 \mathrm{p}$.

Ramirez-Villegas, J.; M. Salazar; A. Jarvis \& C.E. Navarro-Racines (2012). A way forward on adaptation to climate change in Colombian agriculture: perspectives towards 2050. Climatic Change, 115, 611-628.

Suhendi, D.; A.W. Susilo \& S. Mawardi. (2000). Kompatibilitas persilangan beberapa klon kakao (Theobroma cacao L.). Pelita Perkebunan, 16, 85-91.

Suhendi, D.; A.W. Susilo \& S. Mawardi (2004). Analisis daya gabung karakter pertumbuhan vegetatif beberapa klon kakao (Theobroma cacao L.). Zuriat, $15,128-132$.

Susilo, A.W. (2011). Analisis stabilitas dayahasil beberapa hibrida unggul harapan kakao (Theobroma cacao L.) pada lokasi tumbuh berbeda. Pelita Perkebunan, 27, 168-180.

Susilo, A.W. \& I. Anita-Sari (2011). Respons ketahanan beberapa hibrida kakao (Theobroma cacao L.) terhadap serangan penyakit pembuluh kayu (vascularstreak dieback). Pelita Perkebunan, 27, 77-87.

Susilo, A.W; D. Zhang \& L. Motilal (2013). Assessing genetic diversity the cocoa collection (Theobroma cacao L.) resistance to cocoa pod borer using simple sequence repeat (SSR) markers. Pelita Perkebunan 29, 1-9.

Susilo, A.W.; I. Anita-Sari \& S. Mawardi (2013). Seratus tahun pemuliaan kakao di Indonesia. p. 110-121. In: T. Wahyudi, J.B. Baon, S. Abdoellah, Misnawi \& A.W. Susilo(Eds.). Prosiding Simposium Kakao 2012, Padang 5-8 November 2012.

Susilo, A.W. (2015). KW 641, klon unggul harapan kakao bersifat tahan kering. Warta Pusat Penelitian Kopi dan Kakao Indonesia, 27, 1-5. 
Susilo, A.W.; I. Anita-Sari; B. Setyawan; Sukarmin; R. Hartoyo; S. Mawardi \& Misnawi (2016). Usulan Pelepasan Hibrida Unggul Tahan Penyakit Vascular-Streak Dieback (VSD), Sulawesi $1 \times$ KEE 2. Pusat Penelitian Kopi dan Kakao Indonesia. Jember, Indonesia.

Wibaux, T.; D. Snoeck; P. Jagoret \& P.Bastide (2017). Study of tree-to-tree yield variability among seedling-based cocoa populations in an industrial plantation in Côte D'Ivoire. Experimental Agriculture, $1-12$.

Wibawa, A. \& J.B. Baon (2008). Kesesuaian lahan. p. 63-67. In: T. Wahyudi, T.R. Panggabean \& Pujiyanto (Eds.). Panduan Lengkap Kakao Manajemen Agribisnis dari Hulu hingga Hilir. Penebar Swadaya. Jakarta.
Yan, W. \& M.S. Kang (2003). GGE Biplot Analysis: A Graphycal Tool for Breeders, Geneticist, and Agronomists. CRC Press, Boca Raton, Washington DC.

Yang, F.; Y. Wang \& Ling-Feng Miao (2010). Comparative physiological and proteomic responses to drought stress in two poplar species originating from different altitudes. Physiologia Plantarum, 139, 388-400.

Zuidema, P.A.; P.A. Leffelaar; W. Gerritsma; L. Mommer \& N.P.R. Anten (2005). A physiological production model for cocoa (Theobroma cacao): model presentation, validation and application. Agriculture System, 84, 195-225.

$* * 0 * *$ 